JIPS, Vol. 2 No. 1

Halaman: 64 - 76

Mei 2021
Jurnal Inovasi Pembelajaran di Sekolah

DOI: https://doi.org/10.51874/jips.v1i01.8

ISSN 2774-9363 (Cetak)

ISSN 2774-9746 (Online)
JIPS

Jurnal Inovasi Pembelajaran di

Sekolah

\title{
Peningkatan Kinerja Guru dalam Pembuatan Video Pembelajaran Daring melalui Supervisi Individual SD Negeri Kemijen 01 Kota Semarang
}

\author{
Suhartiningsih \\ SD Negeri Kemijen 01 Kota Semarang
}

\begin{abstract}
Abstrak
Latar belakang masalah penelitian ini untuk mengetahui proses pelaksanaan pembuatan video pembelajaran daring melalui supervisi individual dan hasil peningkatan kinerja guru setelah melakukan pembuatan video pembelajaran daring melalui Supervisi Individual.Metode penelitian yang digunakan yaitu metode penelitian tindakan sekolah (PTS) dan data yang digunakan adalah kinerja guru dalam pembuatan video pembelajaran daring melalui supervisi individual. sampel penelitian ini adalah guru SD Negeri Kemijen 01 Kota Semarang yang berjumlah 13 orang.Hasil penelitian peningkatan kinerja guru dalam pembuatan video pembelajaran daring melalui supervisi individual, semakin meningkat hal ini dibuktikan selama penelitian berlangsung dari siklus I prosentasi rata - rata $62 \%$ dapat ditingkatkan pada siklus II menjadi $78 \%$ dengan predikat baik. Supervisi individual dalam pembuatan video .

Hasil peningkatan kinerja guru dalam pembuatan video pembelajaran daring melalui supervisi individual. pembelajaran daring mampu merubah kinerja guru SD Negeri Kemijen 01 Kota Semarang secara signifikan, yang akhirnya berdampak pada perubahan sikap dan perilaku dalam proses pembelajaran daring menghadapi masa pandemi covid-19
\end{abstract}

Kata Kunci : kinerja guru, video pembelajaran

\section{Abstract}

The background of this research problem is to determine the process of making online learning videos through individual supervision and the results of improving teacher performance after making online learning videos through Individual Supervision. The research method used is the school action research method (PTS) and the data used is the teacher's performance in making online learning videos through individual supervision. The sample of this research is 13 teachers of SD Negeri Kemijen 01 Semarang City. The results of the research on improving teacher performance in making online learning videos through individual supervision, this was increasing. This was evidenced during the research that lasted from cycle I, an average percentage of $62 \%$ can be increased in cycle II to $78 \%$ with a good predicate. Individual supervision in making videos. The results of improving teacher performance in making online learning videos through individual supervision. Online learning is able to significantly change the performance of SD Negeri Kemijen 01 Semarang City teachers, which in turn has an impact on changing attitudes and behavior in the online learning process facing the Covid-19 pandemic.

Keywords: teacher performance, instructional videos

\section{PENDAHULUAN}

Problematika pembelajaran daring ini tidak hanya dialami oleh peserta didik, tetapi dengan masih mewabahnya covid-19 sampai dengan akhir tahun ajaran yang mengharuskan guru-guru membuat soal ujian atau penilaian akhir Tahun Pelajaran 2019/2020 dalam bentuk daring, ini juga hal baru bagi guruguru di Indonesia, dengan motivasi yang tinggi akhirnya guru berhasil tetap melakukan Penilaian Akhir Semester (PAS) dengan baik dan tingkat keikutsertaan anak yang sesuai dengan yang diharapkan. 
Peraturan walikota Semarang nomor 57 tahun 2020 tentang pelaksanaan pembatasan kegiatan masyarakat dalam rangka pencegahan pengendalian corona virus disease 2019 (Covid-19) kota Semarang . Dengan adanya perintah belajar dari rumah tersebut tidaklah serta merta dapat diterima dan dilakukan masyarakat kota Semarang, terlebih karena masih terbatasnya kemampuan teknologi komunikasi masyarakat dan juga biaya yang banyak harus dikeluarkan untuk pembelian paket internet bahkan ada yang harus membeli handphone berbasis Android baru untuk menunjang pembelajaran Daring (dalam jaringan) yang dilakukan oleh masing-masing sekolah.

Di sinilah letak peran signifikan seorang Kepala Sekolah untuk tetap menjalankan kepemimpinannya dengan baik di tengah situasi krisis seperti ini. Kepala sekolah dituntut menerapkan "manajemen krisis", yaitu proses mempersiapkan dan mengelola situasi darurat atau tidak terduga yang mempengaruhi peserta didik, guru, staf, dan pemangku kepentingan. Ini merupakan komponen penting dari Public Relation (PR). Ini berbeda dari manajemen risiko, yang mengharuskan kepala sekolah untuk menilai potensi ancaman dan menemukan cara terbaik untuk menghindari ancaman tersebut. Dalam manajemen krisis, ancaman ini sudah terjadi dan harus dihadapi. Ancaman atau krisis yang sedang dihadapi saat ini tidak sepenuhnya buruk bagi sekolah. Sebaliknya, ia justru bisa memotivasi sekolah untuk menjadi lebih baik di masa depan. Contohnya, banyak sekolah yang pada akhirnya melakukan transformasi digital dengan menggunakan aplikasi berbasis web untuk memudahkan proses pembelajaran, rapat, dan koordinasi manajerial ketika harus bekerja dari rumah.

Kepala sekolah sebagai seorang supervisor mempunyai tanggung jawab untuk peningkatan kemampuan guru dalam mengelola kegiatan pembelajaran di sekolah serta mempunyai peranan yang sangat penting terhadap perkembangan dan kemajuan sekolah. Oleh karena itu, kepala sekolah harus melakukan supervisi secara baik dan benar sesuai dengan prinsip-prinsip dan teknik serta pendekatan yang tepat. Pembinaan-pembinaan yang dilakukan oleh kepala sekolah kepada guru dapat meningkatkan kinerja dan dedikasi guru dalam pendidikan. Tugas seorang supervisor adalah membantu, mendorong dan memberikan keyakinan kepada guru bahwa proses belajar mengajar dapat memberikan pengembangan berbagai pengalaman, pengetahuan, sikap dan keterampilan guru serta proses belajar mengajar yang dilakukan oleh guru tersebut harus dibantu secara profesional sehingga guru dapat berkembang dalam pekerjaannya yaitu untuk meningkatkan efektivitas dan efisiensi proses belajar mengajar.

Kepala sekolah sebagai seorang supervisor mempunyai tanggung jawab untuk peningkatan kemampuan guru dalam mengelola kegiatan pembelajaran daring di sekolah serta mempunyai peranan yang sangat penting terhadap perkembangan dan kemajuan sekolah. Di dalam proses belajar mengajar agar pembelajaran efektif maka diperlukan suatu media yang sesuai dengan karakter peserta didik, mata pelajaran yang disampaikan, suasana dan prasarana penunjang. Dengan perangkat pembelajaran yang baik akan menuntun peserta didik untuk dapat meningkatkan hasil belajar dengan baik. Untuk itu pada 
pembelajaran daring diperlukan pembelajaran yang menarik dan memudahkan peserta didik untuk memahami proses pengolahan suatu makanan.

Media pembelajaran adalah saluran atau perantara yang digunakan untuk menyampaikan pesan atau materi ajar. Media sangat diperlukan dalam pembelajaran sebagai alat penyampaian informasi dan pesan dari guru kepada peserta didik. Pembelajaran yang baik dan berlangsung lancar memerlukan media pembelajaran yang baik dan sesuai dengan kondisi kelas. Pembelajaran daring membutuhkan media yang mengandung unsur gerak, oleh karena itu, video pembelajaran merupakan salah satu media yang sesuai untuk menampilkan tahap-tahap dalam proses pembelajaran daring yang disesuaikan dengan materi pembelajaraan secara detail dan terperinci. Media video pembelajaran adalah media atau alat bantu mengajar yang berisi pesan-pesan pembelajaran. Video sebagai media audio visual dan mempunyai unsur gerak akan mampu menarik perhatian dan motivasi peserta didik dalam melaksanakan kegiatan pembelajaran.

Berdasarkan observasi awal melalui supervisi individu yang dilakukan kepala sekolah SD Negeri Kemijen 01yang juga sebagai peneliti terlihat permasalahan guru di SD Negeri Kemijen 01 dalam pembelajaran daring ini adalah media video. Selama ini guru dalam memberikan tugas kepada peserta didik yang berupa video hasil dari downloud dari internet juga dalam pemberian tugas hanya mengandalkan video dari kelompok guru kecamatan Semarang Timur yang diunduh melalui gruop media sosial whattshap hal ini sangat mempengaruhi ketergantungan guru di SD Negeri Kemijen 01pada konten orang lain. Peneliti menganggap perlu dilakukan penelitian video pembelajaran dan peneliti akan melakukan penelitian dengan judul " Peningkatan Kinerja Guru Dalam Pembuatan Video Pembelajaran Daring Melalui Supervisi Individual SD Negeri Kemijen 01 Kota Semarang”

\section{KAJIAN PUSTAKA}

\section{Kinerja Guru}

Kinerja memiliki makna yang lebih luas, bukan hanya di katakan sebagai hasil kerja namun juga bagaimana cara mengerjakannya. Kinerja merupakan tentang bagaimana melakukan pekerjaan dan hasil yang dicapai dari pekerjaan tersebut.

\section{a. Faktor-Faktor}

Yang Mempengaruhi Kinerja Guru merupakan ujung tombak keberhasilan pendidikan dan dianggap sebagai orang yang berperan penting dalam pencapaian tujuan pendidikan yang merupakan pencerminan mutu pendidikan. Keberadaan guru dalam melaksankan tugas dan kewajibannya tidak lepas dari pengaruh faktor intenal maupun faktor eksternal yang membawa dampak pada perubahan kinerja guru. Menurut Mangkunegara dalam Endin ada dua faktor yang memengaruhi kinerja, yaitu: Faktor kemampuan (ability) dan faktor motivasi (motivation). faktor kemampuan potensi (IQ) dan kemampuan real (knowledge + 
skill). Artinya, seseorang yang memiliki IQ tinggi dan di tunjang dengan pendidikan yang memadai serta terampil dalam melaksanakan tugasnya, ia akan lebih mudah mencapai kinerja yang diharapkan .

Sementara faktor motivasi terbentuk dari sikap (attitude) seseorang dalam menghadapi situasi kerja. Motivasi merupakan kondisi yang menggerakkan diri seseorang agar terarah untuk mencapai tujuan kerja. Dari penjelasan di atas, dijelaskan bahwa dalam pelaksanaan kinerja guru di pengaruhi oleh dua faktor yaitu faktor kemampuan dan faktor motivasi. Guru memiliki tugas sebagai pendidik harus memiliki kemampuan dalam mendidik muridnya baik itu kemampuan mengajarnya di dalam kelas serta kemampuan mendidik siswanya sesuai dengan tuntutan pendidikan. Selain kemampuan seorang guru juga harus memiliki motivasi dalam bekerja sehingga ia akan mampu menjalankan tugas nya dengan baik dan mampu menghadapi berbagai situasi dalam bekerja.

Dalam Undang-Undang No. 20 Tahun 2003 tentang Sistem Pendidikan Nasional Indonesia Pasal 39 ayat 3 dinyatakan bahwa: Pendidik yang mengajar pada satuan pendidikan dasar dan menengah disebut guru. Sementara itu, tugas guru sebagaimana disebutkan dalam Pasal 39 ayat 2 adalah merencanakan dan melaksanakan proses pembelajaran, menilai hasil pembelajaran, melakukan pembimbingan dan pelatihan, serta melakukan penelitian dan pengabdian kepada masyarakat.

Hal ini berarti bahwa selain mengajar atau proses pembelajaran, guru juga mempunyai tugas melaksanakan pembimbingan maupun pelatihan bahkan perlu melakukan penelitian dan pengabdian kepada masyarakat sekitar.Hal ini berarti bahwa selain mengajar atau proses pembelajaran, guru juga mempunyai tugas melaksanakan pembimbingan maupun pelatihan bahkan perlu melakukan penelitian dan pengabdian kepada masyarakat sekitar. Guru memiliki tanggung jawab besar sebagai pengajar serta pendidik bagi murid-murid.

\section{b. Kinerja Guru Profesional}

Guru merupakan ujung tombak dalam pendidikan oleh karenanya guru dituntut untuk memiliki kinerja yang baik. Untuk dapat memberikan kinerja yang baik maka seorang guru harus menunjukkan keprofesionalan dalam menjalankan bidang pekerjaannya. Seorang guru yang profesional harus memenuhi beberapa persyaratan diantaranya memilki kualifikasi akademik, kompetensi, sertifikat pendidik, sehat jasmani dan rohani, serta memiliki kemampuan untuk mewujudkan tujuan pendidikan nasional (UU no 14 tahun 2005 tentang guru dosen pasal 8).

Kesemua persyaratan tersebut menjadi dasar bagi guru untuk menjalankan tugas dan tanggung jawab yang diembannya. Sebagai seorang yang dianggap menjadi sosok yang penting dalam pendidikan, guru memiliki tugas dan tanggung jawab yang begitu besar baik di lingkup sekolah maupun dalam masyarakat. Ada enam tugas dan tanggung jawab seorang guru yakni bertugas sebagai pengajar, pembimbing, administrator kelas, pengembang kurikulum, mengembangkan profesi, membina hubungan dengan masyarakat (Buchari Alma, 2010: 132). 
Walaupun demikian, secara lebih spesifik guru juga memiliki tugas profesional/ tugas pokok yang harus dikerjakan. Berdasarkan dari penjelasan sebelumnya bahwa seorang guru memiliki tugas utama yang mengarah pada lingkup kegiatan pembelajaran. Kegiatan tersebut meliputi kegiatan merencanakan pembelajaran, melaksanakan pembelajaran, dan mengevaluasi pembelajaran. Pelaksanaan dari ketiga hal tersebut menjadi kunci keberhasilan guru dalam menjalankan tugasnya sebagai pendidik dan juga dapat dijadikan sebagai tolok ukur kinerja guru dalam hal menjalankan tugasnya selama berada disekolah.

Hal ini sama seperti yang dijelaskan oleh Hamzah B. Uno dan Nina Lamatenggo (2012: 63) yang menyatakan: dalam kaitan dengan kinerja guru sekolah dasar, kinerja mereka dapat terefleksi dalam tugasnya sebagai pengajar dan sebagai seorang pelaksana administrator kegiatan mengajarnya. Dengan kata lain, kinerja guru sekolah dasar dapat terlihat pada kegiatan merencanakan, melaksanakan, dan menilai proses belajar mengajar yang intensitasnya dilandasi etos kerja dan disiplin profesional guru. Hal yang sama diungkapkan Soedijarto (2008: 178) bahwa "kinerja guru meliputi merencanakan, mengelola pelaksanaan, menilai proses dan hasil, mendiaknosis kesulitan belajar, dan merevisi program pembelajaran" Berkaitan dengan penjelasan diatas maka kinerja guru profesional dapat dilihat dari bagaimana seorang guru menjalankan tugas utamanya.

Dalam hal ini tugas yang dimaksud adalah tugas guru dalam merencanakan pembelajaran, melaksanakan pembelajaran, dan mengevaluasi pembelajaran. Sehingga dapat disimpulkan bahwa kinerja guru profesional merupakan pelaksanaan tugas-tugas utama guru yang terdiri dari merencanakan, melaksanakan, dan mengevaluasi pembelajaran dengan baik dan sesuai aturan yang telah ditentukan

\section{Supervisi Kepala Sekolah}

Pengertian Supervisi Kepala Sekolah Supervisi secara etimologi berasal dari kata "super" dan "visi” yang mengandung arti melihat dan meninjau dari atas atau menilai dari atas yang dilakukan oleh pihak atasan terhadap aktivitas, kreativitas, dan kinerja bawahan (E. Mulyasa, 2000: 154) Ada beberapa istilah yang hampir sama dengan supervisi bahkan dalam pelaksanaannya istilah-istilah tersebut sering digunakan secara bergantian. Istilah-istilah tersebut antara lain, pengawasan, pemeriksaan dan inspeksi. Pengawasan mengandung arti suatu kegiatan untuk melakukan pengamatan agar pekerjaan dilakukan sesuai dengan ketentuan. Pemeriksaan dimaksudkan untuk melihat bagaimana kegiatan yang dilaksanakan telah mencapai tujuan. Inspeksi dimaksudkan untuk mengetahui kekurangan-kekurangan atau kesalahan yang perlu diperbaiki dalam suatu pekerjaan. Terdapat beberapa tokoh yang mengemukakan pendapatnya tentang supervisi, diantaranya:

1. Ngalim purwanto, berpendapat bahwa supervisi adalah suatu aktivitas yang direncanakan untuk membantu para guru dan pegawai lainnya dalam melakukan pekerjaan mereka secara efektif (2006: 103). Supervisi diartikan sebagai pelayanan yang disediakan oleh pemimpin untuk membantu para 
guru, orang yang dipimpin agar menjadi personil yang cakap sesuai dengan perkembangan ilmu pengetahuan pada umumnya dan pendidikan pada khususnya agar mampu meningkatkan efektivitas proses belajar mengajar di sekolah. Disini supervisi diartikan sebagai suatu usaha layanan dan bantuan berupa bimbingan dari kepala sekolah kepada para guru dan pegawai lainnya.

2. Burhanudin, berpendapat supervisi yaitu bantuan dalam mengembangkan situasi belajar mengajar kearah yang lebih baik, dengan jalan memberikan bimbingan dan pengarahan kepada guru dan pegawai lainnya untuk meningkatkan kualitas kerja mereka dibidang pengajaran dengan berbagaiaspeknya (2006: 285).

3. Hadar Nawawi, berpendapat bahwa supervisi yaitu pelayanan yang disediakan pemimpin untuk membantu agar semakin cakap atau terampil dalam melaksanakan tugas-tugasnya, sesuai dengan tuntuan perkembangan dan kemajuan ilmu pengetahuan dibidang tugasnya tersebut (1996: 196) Dalam kaitannya dengan supervisi yang dilakukan oleh kepala sekolah, menurut Purwanto (2004: 32) pengertian supervisi adalah suatu aktivitas pembinaan yang direncanakan untuk membantu para guru dan pegawai sekolah lainnya dalam melakukan pekerjaan mereka secara efektif. Menurut Jones dalam Mulyasa (2003: 155), supervisi merupakan bagian tak terpisahkan dari seluruh proses administrasi pendidikan yang ditujukan terutama untuk mengembangkan efektivitas kinerja personalia sekolah yang berhubungan dengan tugas-tugas utama pendidikan. Menurut Carter dalam Sahertian (2000: 17), supervisi adalah usaha-usaha dari petugas sekolah dalam memimpin para guru dan pegawai lainnya dalam memperbaiki pengajaran termasuk menstimulasi, menyeleksi pertumbuhan jabatan dan perkembangan para guru serta merevisi tujuan-tujuan pendidikan, bahan pengajaran, dan metode serta evaluasi pengajaran. Dari beberapa pendapat dan pengertian tersebut diatas dapat disimpulkan bahwa supervisi bukanlah kegiatan sesaat seperti inspeksi, tetapi merupakan kegiatan yang berkelanjutan dan berkesinambungan sehingga para guru selalu

\section{Fungsi dan Peran Supervisi}

Fungsi utama supervisi ditujukan pada perbaikan dan peningkatan kualitas pengajaran (Piet A.Sahertian, 2000: 21). Sahertian mengutip analisis yang dikemukakan oleh Swearingan dalam bukunya yang berjudul Supervision of Instruction Fondation and Dimension, mengemukakan ada 8 fungsi supervisi, yaitu:

1. Mengkoordiansi semua usaha sekolah

Adanya perubahan yang terjadi secara terus menerus pada kegiatan sekolah sehingga perlu usaha sekolah untuk melakukan koordinasi yang baik diantara personil sekolah yang meliputi para guru dan pegawai lainnya. Adapun usaha yang perlu dilakukan yaitu:

a) Usaha tiap guru, yaitu setiap guru diberikan kesempatan untuk mengemukakan idenya dan menguraikan materi pelajaran menurut pandangannya kearah peningkatan yang lebih baik. 
b) Usaha-usaha sekolah, dalam menentukan kebijakan, merumuskan tujuan-tujuan atas setiap kegiatan sekolah termasuk program-program sepanjang tahun ajaran perlu ada koordinasi yang baik.

c) Usaha-usaha bagi pertumbuhan jabatan, dalam usaha pertumbuhan jabatan, supervisi memberikan berbagai bentuk kegiatan melalui service training, extension course, workshop, seminar guru-guru, selalu berusaha meningkatkan diri sekaligus mengasah intelektual shingga untuk itu perlu dilakukan koordinasi, tugas mengkoordinasi ini adalah tugas supervisi.

2. Kepemimpinan sekolah

Kepemimpinan yang demokratis itu perlu dikembangkan karena kepemimpinan itu suatu ketrampilan yang harus dipelajari dan itu harus melalui latihan yang terus menerus dengan cara melatih dan memperlengkapi para guru agar mereka memiliki ketrampilan dalam kepemimpinan di sekolah.

3. Memperluas pengalaman guru

Pengalaman terletak pada sifat dasar manusia. Manusia ingin mencapai tujuan yang maksimal perlu belajar dari pengalaman, bila ia mau belajar dari pengalaman nyata di lapangan melalui pengalaman baru ia dapat belajar untuk memperkaya dirinya dengan pengalaman belajar baru.

4. Menstimulasi usaha-usaha sekolah yang kreatif

Supervisi bertugas untuk menciptakan suasana yang memungkinkan para guru dapat berusaha meningkatkan potensi-potensi kreativitas dalam dirinya. Kemampuan untuk menstimulasi para guru agar mereka tidak hanya berdasarkan perintah-perintah atau instruksi dari atasan, tetapi mereka adalah pelaku aktif dalam proses belajar mengajar.

5. Memberikan fasilitas dan penilaian terus menerus

Untuk meningkatkan kualitas sumber daya diperlukan penilaian secara terus menerus karena dengan adanya penilaian dapat diketahui kelamahan dan kelebihan dari hasil dan proses belajar mengajar. Penilaian tersebut harus bersifat menyeluruh dan berkelanjutan. Menyeluruh berarti mencakup semua aspek kegiatan sekolah, berkelanjutan berarti penilaian berlangsung setiap saat, yaitu pada awal, pertengahan dan diakhiri dengan melakukan suatu tugas.

6. Menganalisis situasi belajar mengajar

Fungsi supervisi disini adalah menganalisa faktor-faktor yang mempengaruhi perbaikan belajar mengajar seperti mengenai aktivitas guru dan peserta didik akan memberikan pengalaman dan umpan balik terhadap perbaikan pembelajaran, tugas-tugas pembelajaran dan tujuan pendidikan.

7. Memperlengkapi setiap anggota atau staf dengan pengetahuan dan ketrampilan yang baru. Disini supervisi memberikan dorongan stimulasi dan membantu para guru agar mengembangkan pengetahuan dan ketrampilan dalam mengajar. 
8. Memadukan dan menyelaraskan tujuan-tujuan pendidikan dan membentuk kemampuan-kemampuan. Untuk mencapai tujuan yang lebih tinggi harus berdasarkan tujuan-tujuan sebelumnya, setiap guru pada suatu saat sudah harus mampu mengukur kemampuannya. Mengembangkan kemampuan guru adalah salah satu fungsi supervisi. Menurut Daryanto fungsi atau tugas supervisi adalah:

a) Menjalankan aktivitas untuk mengetahui situasi administrasi pendidikan sebagai kegiatan pendidikan di sekolah dalam segala bidang.

b) Menentukan syarat-syarat yang diperlukan untuk menciptakan situasi pendidikan disekolah.

c) Menjalankan aktivitas untuk mempertinggi hasil dan untuk menghilangkan hambatan-hambatan (1998: 174)

Peran supervisi menurut Sahertian dapat ditinjau dari empat macam peran, yaitu:

a) Koordinator

Sebagai seorang koordiantor ia dapat mengkoordinasi program belajar mengajar, tugas anggota staf dengan berbagai kegiatan yang berbeda-beda diantara para guru.

b) Konsultan

Sebagai konsultan, ia dapat memberikan bantuan bersama mengkonsultasikan masalah yang dialami oleh guru baik secara individual maupun secara kelompok.

c) Pemimpin kelompok

Sebagai pemimpin kelompok, ia dapat memimpin sejumlah staf guru dalam mengembangkan potensi kelompok, pada saat mengembangkan kurikulum, materi pelajaran dan kebutuhan profesional para guru secara bersama-sama. Sebagai pemimpin kelompok ia dapat mengembangkan ketrampilan dan kiat-kiat dalam bekerja untuk kelompok (working for the group), bekerja dengan kelompok (working with the group), dan bekerja melalui kelompok (working through the group).

d) Evaluator

Sebagai evaluator ia dapat membantu para guru dalam menilai hasil dan proses belajar, dapat menilai kurikulum yang sedang dikembangkan. Sebagai seorang pemimpin pendidikan dalam hal ini kepala sekolah yang berfungsi sebagai supervisor nampak dengan jelas peranannya sesuai dengan pengertian hakiki dari supervisi itu sendiri, maka peranan supervisi adalah memberi support (supporting), membantu (assisting) dan mengikutsertakan (2000: 31).

\section{Pembelajaran Daring (dalam jaringan)}

Menurut Sanjaya (2020: 14) pembelajaran daring adalah pembelajaran yang memanfaatkan teknologi atau jaringan internet dalam proses pembelajaran. Perkembangan teknologi secara cepat telah membawa peradaban ini menuju ke revolusi industri 4.0. Saat ini kita berada di zaman dimana teknologi dan internet mendukung berbagai lini kehidupan. Wabah covid-19 mendadak menyerang kita dan semua siswa yang 
tadinya tawar-menawar dengan pemanfaatan teknologi dipaksa untuk menggunakanya. Perubahan drastis ini tentunya tidak mudah diterima bagi sebagian pihak namun untuk saat ini hanya teknologi dengan pembelajaran dari rumahlah yang mampu menjadi jembatan untuk tetap berlangsungnya transfer ilmu. Kartikawati (dalam guru SD Negeri 09 Sanggau Kalimantan Barat) mengatakan pembelajaran daring dirumah tetap dapat dilaksanakan. Dalam hal pelaksanaan belajar dari rumah guru meminta orang tua dan kakak siswa sebagai narasumber yang langkah-langkahnya telah diberikan melalui grup. Untuk laporan pelakasanaan berupa video dan foto harus diposting melalui grup.

Berbeda dengan Timur Setiawan menyampaikan beberapa metode pembelajaran secara daring yang telah ditetapkan yaitu pembelajaran melalui rumah yang dibagikan melalui media sosial (Pengelola Web Kemendikbud, 2020). Menurut Purnomo (dalam pikiran rakyat media network) pembelajaran jarak jauh dengan menerapkan metode pemberian tugas secara daring bagi siswa melalui grup dipandang efektif dalam kondisi darurat karena adanya virus corona seperti ini. Banyak guru yang menggunakan cara-cara beragam belajar di rumah ada yang menggunakan ceramah online, ada yang tetapa menagajar di kelas tetapi divideokan dan kemudian dikirim ke aplikasi siswa (Ashari, 2020). Wabah covid-19 semakin mereba Indonesia tidak luput dari wabah tersebut. Sekolah, Universitas mau tidak mau suka atau tidak suka harus bergerak, turut untuk mengatasi keadaan. Sekolah-sekolah mulai dikosongkan secara massal. Belajar dari rumah menjadi sebuah kepastian untuk memutus rantai covid-19.

Dalam situasi seperti ini semua unsur perlu beradaptasi dengan cepat. Teknologi Informasi (IT) dan komunikasi tidak lagi gagap dengan pemanfaatan teknologi dalam proses belajar mengajar. Pembelajaran melalui audio-visual digital atau menggunakan internet sudah biasa dilakukan sehari-hari, di rumah. Dalam pelaksanaan daring ini seorang guru hendaknya mengetahui langkah-langkah pembelajaran daring yaitu: a. Guru harus memanfaatkan waktu dan memberi tugas via Google Classroom, pre-test atau pemberian tugas dengan pemanfaatan Google Drive. Hal ini mutlak harus dilakukan untuk mentransfer pengetahuan kepada peserta didik b. Guru seorang guru harus menyajikan pembelajaran yang terencana dan efektif dalam keterbatasan waktu. c. Dalam kegiatan akhir pembelajaran daring ini hendaknya seorang guru memberikan penguatan karakter/motivasi kepada siswa yang disampaikan guru kepada wali murid atau siswa agar menjadi siswa yang tangguh dan siap dalam kondisi apapun seperti yang terjadi saat pandemi corona ini

Pembelajaran daring adalah pembelajaran yang dilakukan dirumah atau bisa dimanapun dan kapanpun. Ketika timbul situasi yang darurat seperti ini WHO menyarankan untuk belajar dari rumah (Darmalaksana dkk, 2020: 4). Indonesia spontan menggunakan model pembelajaran ini karena sangat darurat dan belum diketahui sampai kapan akan terjadi pembelajaran daring seperti ini. Pembelajaran daring atau pembelajaran online menjadi satu-satunya model pembelajaran yang digunakan di Indonesia. Maraknya penularan ini covid-19 membuat dunia menjadi resah termasuk Indonesia. Social distancing diterapkan 
oleh pemerintah dalam rangka membatasi interaksi masyarakat dari keramaian dan terhindar dari virus ini.

\section{Video Pembelajaran}

\section{Pengertian Video}

Pembelajaran Menurut Cheppy Riyana (2007) media video pembelajaran adalah media yang menyajikan audio dan visual yang berisi pesan-pesan pembelajaran baik yang berisi konsep, prinsip, prosedur, teori aplikasi pengetahuan untuk membantu pemahaman terhadap suatu materi pembelajaran.

Video merupakan bahan pembelajaran tampak dengar (audio visual) yang dapat digunakan untuk menyampaikan pesan-pesan atau materi pelajaran. Dikatakan tampak dengar karena unsur dengar (audio) dan unsur visual atau video (tampak) dapat disajikan serentak.

Video yaitu bahan pembelajaran yang dikemas melalui pita video dan dapat dilihat melalui video/VCD player yang dihubungkan ke monitor televisi (Sungkono 2003:65).

Media video pembelajaran dapat digolongkan ke dalam jenis media audio visual aids (AVA) atau media yang dapat dilihat dan didengar. Biasanya media ini disimpan dalam bentuk piringan atau pita. Media VCD adalah media dengan sistem penyimpanan dan perekam video dimana signal audio visual direkam pada disk plastic bukan pada pita magnetic (Arsyad 2004:36);

1. Tujuan

Menurut Cheppy Riyana (2007:6) media video pembelajaran sebagai bahan ajar bertujuan untuk :

a. Memperjelas dan mempermudah penyampaian pesan agar tidak terlalu verbalistis.

b. Mengatasi keterbatasan waktu, ruang, dan daya indera peserta didik maupun instruktur 3) Dapat digunakan secara tepat dan bervariasi.

\section{METODE PENELITIAN}

\section{Desain Penelitian}

PTS adalah penelitian yang dilaksanakan oleh peneliti (umumnya juga praktisi) di sekolah untuk membuat peneliti lebih profesional terhadap pekerjaannya, memperbaiki praktik-praktik kerja, dan melakukan inovasi sekolah serta mengembangkan ilmu pengetahuan terapan (professional knowledge). Berdasarkan definisi tersebut, maka ciri utama PTS adalah melakukan tindakan nyata untuk memperbaiki situasi atau melakukan inovasi sekolah dalam upaya meningkatkan mutu pembelajaran sehingga mampu menghasilkan guru yang berpikir kritis, kreatif, inovatif, cakap dalam menyelesaikan masalah, dan bernaluri kewirausahaan.

\section{Subjek dan Objek Penelitian}

Subyek penelitian yang terlibat dalam ujicoba penelitian tindakan adalah sebagai berikut: supervisi individual kepala sekolah terhadap kinerja guru dalam pembuatan video pembelajaran. Obyek 
penelitian ini adalah guru yang berjumlah 13 guru. Tempat penelitian di SD Negeri Kemijen 01 Kota Semarang

Instrumen penelitian yang dapat digunakan antara lain : (1) lembar observasi. Untuk mengumpulkan data aktivitas guru, maka peneliti menggunakan lembar observasi. Pengisian lembar observasi ini diisi oleh observer yaitu kepala sekolah dan guru yang mahir dalam penggunaan audio visual yang dibuat sesuai komponen-komponen kegiatan guru dalam proses pembelajaran dari awal sampai akhir pembelajaran. Selain itu lembar observasi digunakan untuk mengamati dan mencatat aktivitas guru saat pembelajaran daring (2) lembar tes, digunakan untuk mengumpulkan data hasil kegiatan guru sesudah pembelajaran daring untuk meningkatkan hasil penggunaan media audio. Dalam hal ini, peneliti menganalisis data dengan menggunakan teknik analisis deskripsi kualitatif yaitu berupa tindakan observasi adalah hasil pengamatan yang dilakukan oleh peneliti tentang pembelajaran daring.

\section{HASIL DAN PEMBAHASAN}

\section{Hasil}

\section{Siklus I}

Setelah melihat data pra siklus pada kegiatan siklus I peneliti akan memberikan perlakukan berupa pembuatan video pembelajaran daringa dengan supervisi individual dengan tujuan peningkatan kinerja guru. Pelaksanaan siklus I dilakukan selama bulan februari tahun 2021 karena semua guru dalam kegiatan belajar mengajar menggunakan pembelajaran daring dengan sistem bekerja di instansi sekolah atau WFO (Work From Office) dan bekerja di rumaha atau WFH (Work From Home). Kegiatan penelitian ini bisa dilaksakan dan dikerjakan baik di sekolah maupun di dirumah. Kegiatan pada siklus I dilakukan dalam empat (4) tahap yaitu perencanaan, pelaksanaan, pengamatan, dan refleksi, berikut ini penjelasannya.

Data evaluasi pembuatan video pembelajaran daring di SD Negeri Kemijen 01 sudah mengalami perbaikan jika dibandingkan dengan hasil yang diperoleh pada temuan awal, kemampuan guru dalam pembuatan video pada siklus I aspek materi mencapai persentase sebesar 3.8\%, untuk aspek media mencapai persentase $4.7 \%$. sedangkan aspek pemanfaatansebesar $3.8 \%$. untuk nilai rata rata dari 13 guru sebesar $62 \%$ yang berarti mendapat nilai cukup

Pada penelitian ini secara individu yang perlu dapat perhatian khusus dengan nilai kurang sebanyak 6 guru, sedangkan pada tahap pembuatan video pembelajaran daring yang mendapat nilai cukup sebanyak 10 guru, hanya 8 guru yang mendapat nilai cukup itupun masih jauh dari harapan peneliti yang mempunyai target minimal rata rata semua aspek pembelajaran sebesar minimal nilai 70 dan nilai rata rata guru sebesar $70 \%$.

\section{Siklus II}

Hal. 74 
Data yang diperoleh oleh peneliti pada siklus I akan diperbaiki kelemahannya pada siklus II diberikan tindakan berupa video pembelajaran daring melalui supervisi individu dengan memahami kekurangan-kekurangan yang didapat pada siklus I. Siklus 2 terdiri atas beberapa tahap, sama seperti siklus 1 yaitu : (1) Perencanaan, (2) Pelaksanaan, (3) Pengamatan, dan (4) Refleksi.

Berdasarkan data yang diperoleh pada akhir siklus I tentang peningkatan kinerja guru dengan nilai cukup dan hasil evaluasi pada siklus II dengan perubahan kinerja guru mendapat nilai baik, dapat disimpulkan bahwa penelitian tindakan sekolah kali ini membawa keberhasilan sesuai yang diharapkan oleh peneliti, karena itu peneliti tidak perlu melanjutkan ke siklus berikutnya, cukup pada siklus ke II saja. Dan selanjutnya dapat dikembangkan pada kegiatan - kegiatan lainnya yang sekiranya memungkinkan dan cocok untuk menerapkan supervisi individu dalam kegiatan ini. Optimalisasi ini selain dapat meningkatkan kemampuan pembuatan video pembelajaran daring juga dapat berpengaruh pada meningkatnya kinerja guru SD Negeri Kemijen 01.

\section{Pembahasan Hasil Penelitian}

1. Proses Pelaksanaan Pembuatan Video pembelajaran daring Daring Melalui Supervisi Individual SD Negeri Kemijen 01 Kota Semarang

Supervisi individu merupakan tanggung jawab dan kewajiban seorang kepala sekolah untuk melakukannya pada para guru di lingkungan kerjanya. Supervisi individual adalah berupa bantuan /bimbingan yang selayaknya diberikan pada kepala sekolah/penelti dalam rangka meningkatkan kemampuannya dalam melaksanakan proses belajar mengajar disekolah. Pelaksanaan supervisi individual yang dilakukan peneliti mampu untuk memperbaiki dan meningkatkan kompetensi kepala sekolah/penelti sekolah dasar negeri SD Negeri Kemijen 01 Kota Semarang.

2. Peningkatan Kinerja Guru Setelah Melakukan Pembuatan Video Pembelajaran Daring Melalui Supervisi Individual SD Negeri Kemijen 01 Kota Semarang.

Hasil pelaksanaan supervisi individual dapat mengoptimalisasikan kinerja guru. Hasil supervisi berdampak pada perubahan perilaku berupa tanggung jawab, etos kerja, kedisiplinan, keseriusan, kekeluargaan, tim workdalam pembuatan video pembelajaran daring. Kinerja guru menunjukkan adanya peningkatan hasil yang cukup nyata selama tindakan dilaksanakan, apalagi tuntutan jaman kinerja guru dalam pengembangan ilmu teknologi sangat dibutuhkan dalam pembelajaran daring. Peningkatan kinerja guru dibuktikan dengan prestasi sendiri dalam masa covid-19 sudah dapat menghasilkan karya yang berupa video pembelajaran dengan model guru SD Negeri Kemijen 01.

\begin{tabular}{|c|c|c|c|c|c|}
\hline & \multicolumn{5}{|c|}{ ASPEK PENELITIAN } \\
\cline { 2 - 6 } & Materi & Media & Kemanfaatan & Rata-rata & Nilai \\
\hline Siklus I & 3.8 & 4.7 & 3.8 & 62 & Cukup \\
\hline Siklus II & 4,8 & 5,6 & 5,1 & 78 & Baik \\
\hline
\end{tabular}




\section{DAFTAR PUSTAKA}

A.A. Anwar Prabu Mangkunegara. (2001), Manajemen sumber daya manusia perusahaan, Bandung : Remaja Rosdakarya

Abdullah, Burhanuddin. 2006. Ekonomi Berkelanjutan. Jakarta. LP3ES

Abdullah, Ridwan. (2020). Inovasi Pembelajaran. Jakarta: Bumi Aksara

Ahmad Rofi'uddin dan Darmiyati Zuhdi. (1996). Pendidikan Bahasa dan Sastra Indonesia di Kelas Tinggi. Jakarta: Depdikbud

Alma, Buchari (2010: 117) Guru professional: Mengusai Metode dan Terampil Mengajar Bandung: Alfabeta

Alviah, Rina. 2012. "Pengaruh Motivasi Dan Supervisi Terhadap Kinerja Guru TK Dharmawanita Karangwaru Tulungagung". Jurnal Otonomi. Vol.12 No. 2.

A Piet Sahertian, (2000) Konsep Dasar dan Teknik Supervisi, Jakarta : Penerbit Rineka Cipta,

Ashari, M. (2020). Proses Pembelajaran Daring di Tengah Antisipasi Penyebaran Virus Corona Dinilai Belum Maksimal. Pikiran Rakyat com. https://www.pikiran-rakyat.com/pendidikan/pr01353818/proses pembejalaran daring di tengah antisipasi penyebaran virus corona dinilai belum maksimal

Depdiknas .2003. Undang-undang RI No.20 tahun 2003.tentang sistem pendidikan nasional.

Daryanto. (1998). Media Pembelajaran. Yogyakarta: Gava Media.

Hariandja dan Marihot Tua Efendi, Manajemen Sumber Daya Manusia, (Jakarta, Grasindo, 2002 ).

Mulyasa, E.(2000). Kurikulum Berbasis Kompetensi. Bandung: Penerbit PT Remaja Rosdakarya

Nawawi, Hadari. (2004). Evaluasi dan manajemen kinerja di lingkungan perusahaan dan industri. Yogyakarta: Gadjah Mada Univercity Press.

Purwanto, Ngalim. (2006). Psikologi Pendidikan. Bandung: PT Remaja Rosdakarya

Purwanto. 2004. Psikologi Pendidikan. Cetakan ke 20. Bandung: Remaja Rosdakarya

Sedarmayanti. (2008). Sumber Daya Manusia dan Produktivitas Kerja. Bandung: CV Mandar Maju.

Sanjaya, Wina. 2020. "Strategi Pembelajaran Berorientasi Standar Proses Pendidikan". Bandung: Kencana.

Soedijarto, 2008. Landasan dan Arah Pendidikan Nasional Kita. Jakarta : Kompas

Suwatno dan Donni Juni Priansa. 2011. Manajemen Sumber Daya Manusia Dalam Organisasi Publik Dan Bisnis. Bandung : Cv. Alfabeta.

Sugiarti, Titik. 1997. "Motivasi Belajar". Jakarta: Cerdas Pustaka.

Uno, Hamzah.B, dan Nina Lamatenggo. 2012. Teori Kinerja Dan Pengukurannya. Jakarta: PT. Bumi Aksara. 